\title{
Urban Principals' Experiences and Perceptions of Teacher Effectiveness: An Analysis of Student Achievement, Hiring and Retention, and School Culture
}

Carlos Nevarez,

Associate Professor, Department of Educational Leadership and Policy Studies, California State University, Sacramento

J. Luke Wood,

Doctoral Student, Division of Educational Leadership and Policy Studies, Arizona State University

\begin{abstract}
In an effort to promote school improvement principals have primarily focused on developing quality teachers as a method of enhancing the academic achievement of students. This article seeks to shed light on the experiences and perceptions of urban principals regarding teacher effectiveness. Specifically, this article focuses on principals' outlooks on teachers' in three areas: student achievement, hiring and retention, and school culture. Empirical data from this study was derived from a mixed-method cross sectional survey administered to urban school principals in Arizona and California. It was evident in this study that principals perceive teachers as either well qualified or very well qualified to educate urban students. These findings are incongruent with the greater literature on this topic which illustrates the quality of urban school teachers is in question in comparison to non-urban teachers. The implications of principals' overwhelmingly positive outlook are discussed coupled with recommendations for future research.
\end{abstract}

As the United States progresses toward the end of the first decade of the twenty-first century, it is becoming increasingly evident that both the world and the nation that we live in are rapidly changing. Significant demographic changes coupled with globalization, the privatization of education, and issues of accountability have fueled the fire of debate over the need for greater emphasis on student academic achievement. The plight of urban schooling in addressing the aforementioned changes has become even more central to these discussions as many scholars note the imperative national need for successfully preparing urban students to meet the educational demands of this new age (Anyon, 2005; Kozol, 1991; Ladson-Billings, 1994; Noguera, 2003). This becomes more paramount considering fourteen million children reside in urban K-12 public schools (Haberman, 2005). These schools are faced with societal, political, and economic obstacles in conjunction with barriers brought about by poverty, all of which exacerbate student academic success (Henig, Hula, Orr, Pedescleaux, 1999; Nevarez \& Wood, 2007).

In the midst of these challenges urban principals and teachers are increasingly being held accountable for assuring that schools are making progress toward increasing the academic success of urban students. Principals are now expected to be central figures in building schools that develop and promote success for all students. This expectation has changed from the role of principals as enforcers who maintain the 'status quo' (Normore, 2004). In an effort to promote school improvement, principals have primarily focused on developing quality teachers as a method of improving the academic achievement of students. Bearing this in mind, this article seeks to shed light on the experiences and perceptions of urban principals regarding teacher effectiveness. Specifically, this article focuses on principals' outlook on teachers' in three areas: student achievement, hiring and retention, and school culture.

It is essential for urban principals to understand the scope of the challenges faced by teachers in their efforts to support them through the allocation of resources and services which leads to improved teaching and instruction. This is paramount considering that 29 percent of teachers leave the profession within three years and 50 percent of urban teachers leave the teaching profession within five 
Table 1

Number and Percentage Distribution of City Public Elementary and Secondary Students, by Race/Ethnicity : 2003-04

\begin{tabular}{ccccc}
\hline White & Black & Hispanic & $\begin{array}{c}\text { Asian/ } \\
\text { Pacific Islander }\end{array}$ & $\begin{array}{c}\text { American Indian/ } \\
\text { Alaskan Native }\end{array}$ \\
$5,049,347$ & $3,998,670$ & $4,243,922$ & 945,856 & 120,939 \\
$(35.2 \%)$ & $(27.8 \%)$ & $(29.6 \%)$ & $(6.6 \%)$ & $(0.8 \%)$
\end{tabular}

Source: U.S. Department of Education, National Center for Education Statistics, Common Core of Data (CCD), "Public Elementary/ Secondary School Universe Survey," 2003-04.

years. The primary reason teachers report for leaving is a of lack of support from school administrators in conjunction with teachers not feeling educationally and professionally prepared for the continuous and increasing demands of teaching in urban schools (Education Commission of the States, 2003; McKinney, Haberman, Stafford-Johnson, and Robinson, 2008).

\section{Demographic Setting}

Urban schools continue to be racially and ethnically diverse (Dittman, 2004; Orfield and Lee, 2004). Data on urban schools reveals an over-representation of poor and students of color ${ }^{1}$ as compared to the national demographics of the United States. In analyzing population data and projections, it is evident that between the years 2000 and 2050, the percentage of Caucasians in the United States will decrease from 69.4 percent to 50.1 percent, a total decline of 19.3 percent. As this decrease is taking place, the Hispanic population $^{2}$ will experience a marked increase from 12.6 percent to 24.4 percent, a total increase of 11.8 percent. A rise in population percentage among other groups of color will also take place, though to a lesser degree: African Americans from 12.7 percent to 14.6 percent; Asian Americans from 3.8 percent to 8.0 percent; and Native Americans from 2.4 percent to 4.4 percent (U.S. Census Bureau, 1996; U.S. Census Bureau, 2003-04). Table $1^{3}$ illustrates the percentage of racial and ethnic students attending public K-12 schools, 64.8 percent

1 Students of color-" is used to reference African Americans, Hispanic/Latinos, Native Americans, and Asian Americans" (Nevarez \& Wood, 2007, p. 277).

2 "The terms Hispanic and Latino are used interchangeably to refer to persons of Mexican, Puerto Rican, Cuban, Central and South American, Dominican, Spanish, and other Latin American descent" (Nevarez \& Wood, p. 277).

3 Construct for classifying people with similar biological, social, and cultural heritage. of city/urban student enrollment is comprised of students of color. Of these students, the vast majority are Black (27.8 percent) and Hispanic (29.6 percent).

The trajectory of demographic figures for poverty and race/ethnicity becomes more apparent when viewed from national racial/ethnic data as well as poverty data in relation to urban school settings. According to the National Poverty Center (2004), 12.7 percent of people living in the United States lived in poverty and although children represented only 25 percent of the national population, they account for 35 percent of the poor. Sixty eight percent of these economically poor children are concentrated in urban schools (US Department of Commerce, 2003-04). The poverty levels are more apparent when data is disaggregated based upon racial/ethnic affiliation. Table 2 shows that Hispanics and Blacks comprise the majority of students in poverty.

Poverty is a barrier to academic achievement and thus is a monumental issue facing city/urban public schools. Large concentrations of students in urban schools are from economically disadvantaged families (Lippman, 1996; Porter \& Soper, 2003). In fact, 40 percent of students in urban schools are in poverty (Lippman, Burns, McArthur, Burton \& Smith, 1996). Sanders (1999) notes that students living at or near the poverty line are often viewed stereotypically as being less academically skilled than other students. As a result, they are often placed into lower- level and lower-performing classes. Berliner (2006), in a critique of the impact poverty has on urban schooling, states that students in low-income communities are not as successful in school as students from affluent communities. He attributes this inequitable performance to non school-related factors including inadequate day care, environmental issues, low employment rates, and minimal access to technology.

In addition to the impact of poverty on individual students, the income of families dwelling within a school district can have a direct affect on the financial stability of the school. According to Anyon (2005) the fiscal viability of schools are related to the tax base of residents within a schools district. Thus, the lower the tax base, the less funding 
Table 2

Children under 18 Living in Poverty, by Race: 2004

\begin{tabular}{ccccc}
\hline Caucasian & Black & Hispanic & Asian & Total \\
4,507 & 4,049 & 4,102 & 334 & 13,027 \\
$(10.5 \%)$ & $(33.2 \%)$ & $(28.9 \%)$ & $(9.8 \%)$ & $(17.8 \%)$
\end{tabular}

Source: U.S. Bureau of the Census (2004). Income, Poverty, and Health Insurance Coverage in the United States: Report P60. Washington, DC: Author. Retrieved July 11, 2008, from: http://www.npc.umich.edu/poverty

a school may receive. Darling-Hammond (2007) states that:

The continuing segregation of neighborhoods and communities intersects with the inequities created by property tax revenues, funding formulas, and school administration practices that create substantial differences in the educational resources... funding systems and other policies create a situation in which urban districts receive fewer resources than their suburban neighbors (p. 320-321)

These funding inequities result not only in facilities which are outdated (Cortese, 2007) but more importantly, influence the quality ${ }^{4}$ of teachers in urban schools. School funding impacts teacher quality because urban school districts often do not possess the fiscal vitality to guarantee subsequent year job stability. Thus, teachers may be forced to renew their contracts each year. Suburban districts may be more likely to ensure stable employment for teachers as well as hire them early. As a result, many suburban districts have already completed their hiring cycles while urban districts are getting prepared to renew contracts. Teachers seeking stability are then hired first by suburban districts. Due to this process, the tendency for urban districts to hire inexperienced and uncertified teachers increases substantially (Stotko, Ingram, \& Beaty-O'Ferrall, 2007). Humphrey, Koppich, and Hough (2005) note that an unequal representation of certified teachers is apparent in low-performing schools. They state that only 12 percent of certified teachers are in low-performing schools and only 16 percent in schools that have three-quarters or more students of color. In addition to a lack of certified teachers, urban schools are also significantly more likely than suburban schools to have less experienced and first-year teachers (Marnie, 2002). This concentration of less experienced and uncertified teachers in urban schools is disconcerting considering that teacher quality is directly related to student academic success (Brown, 2002; Carter, 2001).

4 This study defines teacher quality as "teachers' preparation, their qualification and the nature of the environments in which they work" (Young, Grant, Montbriand \& Therriault, 2001).

\section{Educational Hurdles}

Academic achievement in urban schools is an issue of continuous concern, especially related to low income and students of color. According to the Council of Great City Schools (2005) academic achievement in math and reading among these groups of students was far below national standards. They report that urban districts scored below state averages in National Assessment of Educational Progress (NAEP) test scores (85.7 percent for math and 83.9 percent for reading). An analysis of NAEP test scores from large central cities makes apparent that nearly half of urban school students are below basic in 8th grade math as well as 4th and 8th grade English (2005a, 2005b).

Low test scores in math and English correlate with low graduation rates among high school students (graduation rates being one measure of academic achievement). Swanson (2008), in an analysis of graduation rates in the largest cities in the United States, found that "only about one-half (52 percent) of students in ... school systems of the 50 largest cities complete high school with a diploma" (p. 8). Swanson also found that graduation rates for many underrepresented students of color in these urban districts were dismal (Native Americans 49.3 percent, Blacks 53.4 percent, and Hispanics 57.8 percent). While these numbers are low, it is important to recognize that these percentages are averages among a select group of schools. As an illustration, the graduation rates for school districts serving the nation's 50 largest cities, in 2003-2004 the Detroit City School District had a graduation rate of 24.9 percent versus 77.1 percent for the Mesa, Arizona Unified School District (Swanson, 2008). An abundance of implications directly result from low academic attainment and achievement. Among those ramifications is the underrepresentation/preparation of urban students when transitioning from high school to college.

Low representation and preparation for college often results in a limited number of these students entering the teacher pipeline. Gay, Dingus, and Jackson (2003) report that there is a large representation of students of color in public schools, at the same time there is an under-representation of teachers of color. Under-representation is a significant factor in aiding the academic success of students given the 
Table 3

National Assessment of Educational Progress-Urban School District Assessment Large Central Cities

\begin{tabular}{lcccc}
\hline & Below Basic & Basic & Proficient & Advanced \\
Math - 4th Grade & $32 \%$ & $43 \%$ & $21 \%$ & $3 \%$ \\
Math - 8th Grade & $47 \%$ & $34 \%$ & $15 \%$ & $4 \%$ \\
English - 4th Grade & $51 \%$ & $29 \%$ & $15 \%$ & $4 \%$ \\
English - 8th Grade & $40 \%$ & $40 \%$ & $18 \%$ & $2 \%$ \\
\hline
\end{tabular}

Source: National Assessment of Educational Progress. (2005). The Nation's Report Card: Trial Urban District AssessmentMathematics. Washington, DC: U.S. Department of Education. National Assessment of Educational Progress. (2005). The Nation's Report Card: Trial Urban District Assessment-Reading. Washington, DC: U.S. Department of Education.

Table 4

Principals in Public and Private Elementary and Secondary Schools, by Selected Race: 1993-94 and 2003-04

\begin{tabular}{ccccccc}
\hline & Caucasian & Black & Hispanic & Asian & American Indian & Total \\
$1993-94$ & 67,808 & 8,020 & 3,270 & 620 & 630 & 79,620 \\
& $(84.2 \%)$ & $(10.0 \%)$ & $(4.1 \%)$ & $(0.7 \%)$ & $(0.7 \%)$ & 87,620 \\
$2003-2004$ & 72,200 & 9,250 & 7,680 & 460 & 600 & $(0.6 \%)$
\end{tabular}

Source: U.S. Department of Education, National Center for Education Statistics, Schools and Staffing Survey (SASS), "Public School Principal Questionnaire" and "Private School Principal Questionnaire," 1993-94, 1999-2000, and 2003-04. (This table was prepared June 2006.)

contributions of teachers of color. Nevarez and Wood (2009) provide five primary themes that epitomize the contributions teachers of color make: a) preparing students for a diverse global marketplace; b) promoting civic engagement and social justice; c) creating quality role models; d) providing cultural brokers/translators/transformers; and e) encouraging critical pedagogy that empowers students to become reflective thinkers around issues of equity and social justice.

According to the U.S. Department of Education (200304b), 71 percent of urban public elementary and secondary school teachers areWhite, while the percentage representation of teachers of color is as follows: Black 15 percent, Hispanic 10 percent, and Other ${ }^{5} 4$ percent. Similarly the underrepresentation of principals of color is to be expected as principals, almost invariably, progress through this teaching pool. In fact, the racial makeup of urban school principals in the United States reveals dismal racial diversity (Gardiner and Enomoto, 2006). Table 4 illustrates racial and ethnic

5 Asians/Pacific Islanders, American Indians/Alaska Natives, and those of more than one race. demographic trends for principals. Blacks and Hispanics have made minimal gains between 1993-94 and 2003-04 (Blacks rose from 10 percent to 10.5 percent and Hispanics from 4.1percent to 5.3 percent). Additionally, this representation pales in comparison to Caucasian public school principals who accounted for 82.4 percent of principals in 2003-2004.

The changing demographic composition of urban students coupled with the lack of representation of teachers and principals of color requires urban institutions to modify, delete, or create new practices and policies with a focus on increasing the diversity of personnel. For instance, Nevarez and Wood (2007) cite the National Collaborative on Diversity in the Teaching Force (2004) in providing a rationale for the benefits of having a diverse leadership pool, four advantages to increasing the number of principals and superintendents of color: (a) their presences produce more mentors and role models for students, (b) they create more occasions for students to increase knowledge of their own racial/ethnic identity, (c) they are able to establish better relationships with students of color because of shared racial, ethnic, and cultural identities, and $(d)$ they guide these students through 
Table 5

Teacher Ability to Raise Student Achievement

$\begin{array}{cccc}\text { All of My Teachers } & \text { Most of My Teachers } & \text { Half of My Teachers } & \text { Some of My Teachers } \\ 4,507 & 4,049 & 4,102 & 334 \\ (10.5 \%) & (33.2 \%) & (28.9 \%) & (9.8 \%)\end{array}$

a system that was developed to be counterproductive to their academic success (p. 270).

Consequently, teachers and principals who are socialized within communities of color are more prone to take on an efficacious role in improving the academic performance of students of color (Ladson-Billings, 1994). This is based not solely on racial/ethnic affiliation, but on lived experiences which allow individuals to get a first-hand look at the plight of urban students. These characteristics can be acquired by anyone independent of race/ethnicity. However, because of the fragmented societal segregation of various racial/ethnic groups, individuals are not afforded the opportunity to learn about individuals that are different than themselves.

\section{Methodology}

Data from this study was derived from a mixed-method cross sectional survey administered to urban school principals in Arizona and California. The survey was piloted with a small group of faculty members in order to refine the instrument and eliminate leading or biased questions. The test group was comprised of fifteen faculty members, all former urban principals. E-mails of participants were collected from the Arizona and California Department of Education web sites. The survey was disseminated via an internet survey distribution system, utilizing a non-probability quota sampling technique. The survey was open for three weeks in each state and periodic reminders were sent to participants who had either started and/or not completed the survey.

There were 68 total respondents in all, 49 from California (CA) and 19 from Arizona (AZ). The gender breakdown of participants ${ }^{6}$ for $C A$ revealed that 31 (63.2 percent) participants were female and 17 (34.6 percent) were male; $A Z$ respondents included 12 female participants (63.1 percent) and 7 male participants (36.8 percent). The racial and ethnic makeup of principals was as follows: CA- 10.2 percent African American; 4 percent Asian American; 57.1 percent Caucasian; 24.4 percent Latino; 2 percent decline to state; and AZ10.5 percent African American; 68.4 percent Caucasian; 21 percent Latino. The respondents represented all levels of K-12 education (elementary (58.8 percent), elementary - middle school (5.8 percent), elementary - high school (1.4 percent)

6 One participant from California did not respond to this question. middle (14.7 percent), middle-high school (2.9 percent), and high school (16.1 percent).

The authors examined urban school principals' experiences and perceptions of teacher effectiveness in three areas: student achievement; hiring and retention, and school culture. Survey questions (Likert-scale and open-ended) were grouped according to these three themes. Teachers' impact on student achievement was based upon five areas of inquiry: 1) principals' perceptions of the extent to which teachers take responsibility for student achievement; 2) principals' experiences regarding whether teachers discuss assumptions about race and student achievement; 3) principals' perceptions of teachers' beliefs in high expectations for all students; 4) principals' experiences with teachers' demonstrated abilities to raise student achievement; and 5) principals' views on whether teachers have the ability to utilize data from student assessments. Teacher Hiring and Retention was informed by four lines of questioning: 1) principals' autonomy in hiring the candidates they desired; 2) principals' experiences with their districts in actively recruiting capable teachers; 3 ) principals' views of their schools' demonstrated commitment to diversity in the teacher recruitment and hiring process; and 4) principals' perceptions of teacher retention within the next two years. Teachers' Familiarity with School Culture was derived from two primary questions which focused on: 1) principals' perceptions of the proportion of teachers who have familiarity with school community; and 2) principals' views on how teachers fit into the school culture.

\section{Findings \\ Student Achievement}

Kunjufu (1989) has written extensively about high expectations in school. He notes that high expectations are essential to the academic success of students of color, particularly African American males. Furthermore, when high expectations of academic excellence exist for all students within a school learning environment, students make greater efforts in meeting those high standards set by the school community. Keeping in mind the importance of high expectations, principals' responses regarding whether teachers' hold high expectations for all students were as follows: 17.6 percent all of my teachers; 60.2 percent most of my teachers, 10.2 percent about half of my teachers; and 11.7 
Table 6

Actively Recruiting Capable Teachers

\begin{tabular}{cccc}
\hline Excellent & Above Average & Below Average & \\
$35.2 \%$ & $42.6 \%$ & $19.1 \%$ & $2.9 \%$ \\
\hline
\end{tabular}

percent some of my teachers.

Bearing in mind the racial implications of expectations for students, principals were also asked whether teachers discuss assumptions about race and student achievement. The participants responded as follows: 4.4 percent strongly agreed, 60.2 percent agreed, 29.4 percent disagreed, and 5.8 percent strongly disagreed. Discussing assumptions about race and its relationship to student achievement is of critical importance; especially considering lingering notions of biological determinism which influences student achievement (see Herrnstein \& Murray, 1994).

As a corollary to this, school principals were asked how much theyagreed or disagreed that teacherstakeresponsibility for student achievement. Of the total respondents 35.2 percent strongly agreed that teachers take responsibility, 57.3 percent agreed, and 7.3 percent disagreed. Additionally, principals were asked about their experiences with teachers in terms of improving student success. Respondents were asked to indicate the proportion of teachers that demonstrate the ability to raise student achievement. A large portion of principals (69.1 percent) stated that all of their teachers or most of their teachers had demonstrated this ability (see Table 5). In contrast, a notable percentage of principals (30.8 percent) stated that only half or some of their teachers have the ability to raise student achievement.

This study also sought to determine whether teachers possess the skills necessary to make use of standardized tests and other forms of assessment. Thus, principals were asked whether teachers have the ability to utilize data from student assessments. Of the total principal responses, 23.5 percent stated all of my teachers, 50 percent most of my teachers, 22 percent about half of my teachers, and 4.4 percent some of my teachers.

\section{Teacher Hiring/Retention}

The survey sought to determine the extent to which principals have autonomy in teacher hiring, through an openended response format. Principals were asked to describe the extent to which you are able to hire your teachers of your choosing. Responses from principals were coded based upon emergent themes. Data coding revealed two major emergent themes; the first was that principals had full hiring autonomy:

"I have the complete power to hire who I think is best

\author{
for my school" \\ -Elementary School Principal, CA \\ "I can hire and fire teachers with full autonomy" \\ -Middle/High School Principal, CA \\ "I hire all of my own teachers" \\ -Elementary School Principal, AZ
}

The second major theme was that principals had indirect influence on hiring through site-based hiring committees. These committees are comprised of teachers and sometimes students as well:

"I put together a team of teachers to interview and make the final decision"

-Elementary School Principal, AZ

"We hire as a committee, but I can recruit/hire teachers I want to have. It's a site decision that includes me. I would not have a whole committee interview someone I would not hire"

-Elementary School Principal, AZ

"Joint effort with site leadership team comprised of all stakeholders, including students"

-High School Principal, CA

While most principals had substantial direct or indirect influence in hiring decisions, a few principals did not. Primarily, their responses indicated hiring challenges due to strong faculty unions or full-district level screening, interviewing, hiring and placement of teachers.

Beyond school level hiring, principals were also asked to describe their experiences with their districts' recruitment of teachers, in terms of teacher quality. Principals were asked whether districts are actively recruiting capable teachers. Table six illustrates that 77.8 percent of principals reported their ability to recruit capable teachers was either excellent or above average.

Principals were also asked whether there was a commitment to diversity in the teacher recruitment and hiring process. Of the total principals, 36.7 percent stated excellent, 48.5 percent above average, 10.2 percent below average, and 
Table 7

Familiarity with School Community

\begin{tabular}{|c|c|c|c|}
\hline All of My Teachers & Most of My Teachers & Half of My Teachers & Some of My Teachers \\
\hline $23.5 \%$ & $50 \%$ & $20.5 \%$ & $5.8 \%$ \\
\hline
\end{tabular}

4.4 percent poor. As indicated by this finding 84.8 percent of principals believe that they are doing excellent or above average in their commitment to diversity.

In addition to hiring, the study sought to understand principals' perceptions of teacher retention. Using a four point Likert-scale question format (with answer types including: most of my teachers; about half of my teachers; some of my teachers, and none of my teachers), participants were asked what proportion of their current teachers will be likely to leave teaching in the next year or two. Of the respondents 1.4 percent answered most of my teachers, 1.4 percent about half of my teachers, 69.1 percent some of my teachers, and 27.9 percent none of my teachers.

\section{Teachers' Familiarity with School Culture}

This survey sought to provide insight into principals perceptions of teachers' familiarity with the school culture and school community. Reinhartz and Beach (2004) provide a simple definition of school culture, "how a school or an organization does things" (p. 27). School culture is comprised of the daily operations, values, and practice employed in a school. School community is a public school that acts as the center point of its community by engaging community resources to offer a range of services and resources that support the success of students and their families (Federation for Community Schools, 2007). Principals were asked to indicate the proportion of their teachers who had familiarity with the school community. The vast majority of responses (73.5 percent) stated that all of their teachers or most of their teachers had familiarity with the school community.

Principals were also asked about the proportion of their teachers who had familiarity with the school culture. Of the respondents, 20.5 percent stated all of my teachers, 64.7 percent most of my teachers, 11.7 percent about half of my teachers, and 2.9 percent some of my teachers. As a result, a large portion of the respondents felt that their teachers had familiarity with the school culture and community. Nevarez and Wood (2007) state that an awareness of the school culture and surrounding community can be utilized by teachers in their efforts to connect students' own life experiences with the curriculum and class assignments which will validate the students' world view. The teacher, in this case, sees the cultural norms of the community as assets in the educational process.

\section{Discussion}

This study broadens the research literature on urban principals' experiences and perceptions of teacher effectiveness. While much more work is warranted in gaining a comprehensive overview of how urban principals experience teachers' effectiveness, this study clearly reveals principals' overall positive outlook on the quality of teachers in three general areas: student achievement, hiring and retention, and school culture. The study's findings offer several consistent results. The most significant results focus on principals' perceptions of teachers' ability to increase student achievement, principals' autonomy in hiring teachers of their choosing, and teachers' familiarity with the school culture and community. These findings are contextualized within the greater literature.

The vast majority of principals either believe that all of their teachers or most of their teachers: a) take responsibility for student achievement; b) demonstrate the ability to raise student achievement; and c) have the ability to utilize data from student assessments. Additionally, views on teachers' means of holding high expectations for students, teachers' ability to raise student achievement, and teachers' efforts to discuss assumptions about race and student achievement were viewed favorably by principals. However, one-third of principals responded that they either disagree or strongly disagree that teachers are not engaging in conversations about student achievement in relation to race/ethnicity. Lindahl (2006) states that it is impossible to discuss closing the achievement gap without acknowledging the role of race and culture, considering students bring their cultural values to the school environment. Teachers' cultural understanding of themselves, the students they teach, the families that raise them and the communities where they reside can be used through curriculum and instruction pedagogy to increase student achievement (Howard, 2006).

Principals also reported having substantial autonomy through direct or indirect influence in hiring teachers of their choosing. According to Papa, Lankford \& Wyckoff (2003) it is important that urban principals have autonomy in the hiring process. They stated, that "it is problematic holding principals accountable when they do not have substantial control and involvement in the process by which teachers are hired" ( $p$. 7). They also note that urban principals have less autonomy in hiring that do their suburban and rural counterparts. In 
contrast to this viewpoint, which is shared by the greater literature review, this study revealed that the vast majority of urban principals have autonomy in hiring teachers of their choosing.

Study results revealed principals' satisfaction with their school district's ability to actively recruit capable teachers and their commitment to diversity in teacher recruitment and hiring. Literature on urban schools suggests that recruiting capable teachers is very difficult (Hill, Campbell, Harvey \& Herdman, 2000; National Commission on Teaching and America's Future, 1996, 2002). The success, or lack thereof, of urban school students is often attributed to low teacher qualifications and quality (Stotko, Ingram, Beaty-O'Ferral, 2007). This finding also tends to differ from the scholarly literature which states that, in general, districts are not doing a good job of diversifying their teacher ranks (Eubanks \& Weaver, 1999; Gay, Dingus \& Jackson, 2003).

In this study, school principals revealed concerns with teacher departure. According to National Commission for Teaching and America's Future (2002) nearly half (46.2 percent) of teachers will leave the profession within five years. This rate is higher for urban and high-poverty schools. For example, the one year teacher turnover rates in suburban schools are 14.9 percent; while urban schools have a 15.9 percent annual turnover rate. However, high-poverty schools have a 20 percent annual turnover rate. Certo \& Fox (2002) state that the primary reasons teachers leave schools are due to poor salaries, inadequate support from campus administration, and minimal time for planning.

In this study, despite concerns about teacher turnover, principals had a favorable view of teachers' familiarity with school and community culture. In contrast, research on urban schools suggests that there is often a cultural disconnect between the teaching force and the students, families and communities that they serve (Eubanks \& Weaver, 1999; Ladson-Billings, 1994; Villegas \& Clewell, 1998; Zeichner, 1996a, 1996b). Consistent with other results from this study, principals perceptions about teachers connectedness to the school culture was viewed favorably.

\section{Conclusion}

Urban principals' approaches to leading urban schools depend largely on their own views toward teacher effectiveness. It was evident in this study that principals perceive teachers as either well qualified or very well qualified to educate urban students. Although teacher quality is cited as one of the main factors in academic achievement, these findings are incongruent with the greater literature on this topic which illustrates that urban school districts perform considerably below their suburban counterparts. Further, they face challenging contextual circumstances mainly due to added barriers derived from poverty.

What are the implications of principals' overwhelmingly positive outlooks on the condition of urban schools and teacher effectiveness? The researchers' have identified four possible implications of these findings. One explanation of principals' positive outlook is that it negates teacher and school limitations, which in turn, can lead to a lack of motivation to improve teaching effectiveness and student achievement. Rather masking limitations through a positive outlook, recognizing areas of weakness can serve as a prerequisite for improvement. Secondly, although the urban education literature abounds with books, reports, and articles explaining the challenging plight of urban teachers and their efforts to increase achievement, it is plausible that selected urban schools and respective teachers for this study are doing exemplary work. In this case, it would behoove researchers to revisit these schools and be thorough in investigating issues which provide validation of principals' experiences and perceptions of teacher effectiveness. A third alternative for this study's findings could be the degree to which principals believe that teachers are able to raise student achievement. It is possible that principals perceive even a limited ability to increase achievement, as a demonstrated ability, nonetheless. Thus, future studies could examine this alternative by eliciting the degree to which principals believe that teachers raise achievement. Finally, these findings may illustrate the existence of two, often divergent, schools of thought in education regarding the primary reason why low student achievement is chronic in urban schools. One school places the focus of inequitable student outcomes on educational institutions. Researchers with this orientation focus on low student achievement as a by-product of ineffective school leadership, teachers, pedagogy and curriculum (e.g. Murrell, 2002; Ross, McDonald, Alberg, McSparrin-Gallagher, 2005, 2007). The other school of thought contextualizes student success issues in schooling within the community and greater socio-economic and political environment in which urban students reside (Anyon, 2005). It is possible, that principals selected for this study are emphasizing the latter position. Regardless of which implication(s) are the most salient, it is clear that the disconnect between urban principals' perceptions of their schools and the literature on teacher effectiveness is an issue that is in need of further research.

\section{REFERENCES}

Anyon, J. (2005). Radical possibilities: Public policy, urban education, and a new social movement. New York: Routledge/ Falmer.

Berliner, D. C. (2006). Our impoverished view of educational reform. Teachers College.

Record, 108(6), 949-995.

Brown, D.F. (2002). Becoming a successful urban teacher. Portsmouth, NH: Neinemann. 
California Department of Education. (2007). Graduates with UC/CSU required courses by ethnicity: Los Angeles County, (2005-06). Sacramento, CA: CDE Educational Demographics Office.

Carter, S. (2001). No excuses: Lessons from 21 high-performing, high-poverty schools. Washington, DC: Heritage Foundation.

Certo, J. L., \& Fox, J. E. (2002). Retaining quality teachers. The High School Journal, 86(1), 57-75.

Cortese, A. (2007). Here's the boost that poor children, their teachers, and their schools really need. Washington, DC: American Federation of Teachers. Retrieved February 19, 2008, from: http://www.aft.org/pubs-reports/american educator/ issues/spring07/GetReal.htm

Council of the Great City Schools. (2005). Beating the odds: A city-by-city analysis of student performance and achievement gaps on state assessments. Washington, DC: Author. Retrieved April 11, 2008, from: http://www.cgcs.org/ pdfs/BTOVFINALFULLCOPY3.30.05.pdf.

Darling-Hammond, L. (2007). The Flat Earth and Education: How America's Commitment to Equity Will Determine Our Future. Educational Researcher, 36, 318-334.

Dittman, M. (2004). Fifty years later: Desegregating urban schools. Monitor on Psychology, 35, 62.

Education Commission oftheStates.(2003). Recruitingteachers of color: A program overview. Retrieved April 4, 2008, from: http://www.communityteachers.org/documents/Recruiting percent20eacherspercent20of percent20Color percent20percent20A percent20Programpercent200verview.pdf.

Eubanks, S. C., \& Weaver, R. (1999). Excellence through diversity: Connecting the teacher quality and teacher diversity agendas. Journal of Negro Education, 68(3): 451-459.

Federation for Community Schools (2007). Retrieved July 7, 2008, from: http://www.ilcommunityschools.org/what1.asp

Gardiner, M. \& Enomoto, E. (2006). Urban school principals and their role as multicultural leaders. Urban Education, 41, 560-585.

Gay, G., Dingus, J., \& Jackson, C. (2003). The presence and performance of teachers of color in the profession. Landover, MD: Community Teachers Institute. Retrieved April 9, 2008, from: http://www.communityteachers.org/reports/ PresPerfTeachersofColoringProfess.pdf
Haberman, M. (2005). Star teachers: The ideology and best practice of effective teachers of diverse children and youth in poverty. Houston, TX: The Haberman Educational Foundation.

Henig, J. R., Hula, R. C., Orr, M., \& Pedescleaux, D. S. (1999). The color of school reform: Race, politics, and the challenge of urban education. New Jersey: Princeton University Press.

Herrnstein, R. J., \& Murray, C. (1994). The bell curve. New York: Free Press.

Hill, P. T., Campbell, C., \& Harvey, J. (2000). It takes a city: Getting serious about urban school reform. Washington, DC: Brookings Institution Press.

Howard, G. (2006). We can't teach what we don't know: White teachers, multicultural schools (2nd ed.). New York: Teachers College Press.

Humphrey, D. C., Koppich, J. E., \& Hough, H. J. (2005). Sharing the wealth: National Board Certified Teachers and the students who need them most. Education Policy Analysis Archives, 13, 1-50. http://epaa.asu.edu/epaa/v13n18/.

Kozol. J. (1991). Savage inequalities: Children in America's schools. New York: Harper Perennial.

Ladson-Billings, G. (1994). The dreamkeepers: Successful teachers of African American children. San Francisco: Jossey Bass.

Lindahl, R. (2006). The role of organizational climate and culture in the school improvement process: A review of the knowledge Base. Retrieved June 15, 2008 from http://cns.org/ content/m13465/latest.

Lippman, L. (1996). Urban schools: The challenge of location and poverty. Washington, DC: National Center for Education Statistics.

Lippman, L., Burns, S., McArthur, E., Burton, R., \& Smith, T. M. (1996). Urban schools: The challenge of location and poverty. National Council for Education Statistics.

Logan, John, Jacob Stowell, and Deirdre Oakley. 2002. Choosing Segregation: Racial Imbalance in American Public schools, 1990-2000.Albany, NY: Lewis Mumford Center for Comparative Urban and Regional Research.

Marnie, S. (2002). School finance: Per-pupil spending differences between selected inner city and suburban schools varied by metropolitan area. Report to the Ranking Minority Member, Committee on Ways and Means, House of Representatives. Washington, DC: General Accounting Office. 
McKinney, S. E., Haberman, M., Stafford-Johnson, D., \& Robinson, J. (2008). Developing teachers for high-poverty schools: The role of the internship experience. Urban Education, 43(1), 68-82.

Murrell, Peter. 2002. African-Centered Pedagogy: Developing Schools of Achievement for African American Children. New York, NY: State University of New York Press.

National Assessment of Educational Progress. (2005a). The nation's report card: Trial urban district assessmentmathematics. Washington, DC: U.S. Department of Education. Retrieved April 4, 2008, from: http://nationsreportcard.gov/ tuda_reading_mathematics_2005/t0002.asp?printver=

National Assessment of Educational Progress. (2005b). The nation's report card: Trial urban district assessment-reading. Washington, DC: U.S. Department of Education. Retrieved April 4, 2008, from: http://nces.ed.gov/nationsreportcard/ pdf/dst2005/2006455r.pdf

National Collaborative on Diversity in the Teaching Force. 2004. Assessment of diversity in America's teaching force: A call to action. Washington, DC. http://www.nea.org/teacherquality/ images/diversityreport.pdf.

National Commission on Teaching and America's Future. (1996). What matters most: Teaching and America's future. New York: Author.

National Commission for Teaching and America's Future. 2002. Unraveling the "teacher shortage" problem: Teacher retention is the key. Washington, DC: U.S. Government Printing Office.

National Poverty Center. (2004). Poverty in the United States: Frequently asked questions. Ann Arbor, Ml: Author. Retrieved April 19, 2008, from: http://www.npc.umich.edu/poverty/\#2.

Nevarez, C. \& Wood, J.L. (2007). Developing urban school leaders: Building on solutions 15 years after the Los Angeles riots. Educational Studies, 42(3), 266-280.

Nevarez, C. \& Wood, J.L. (2009). Benefits of Teachers of Color: Architects in Closing the Achievement Gap. Presented at the Annual Meeting of the American Educational Research Association, San Diego.

Noguera, P. (2003). City schools and the American dream: Reclaiming the promise of public education. New York: Teachers College Press.

Normore, A.H. (2004). The edge of chaos:School administrators and accountability. Journal of Educational Administration,
42(1), 55-77. Retrieved June 18, 2008, from ABI/INFORM Global database. (Document ID: 579702321).

Orfield, G., \& Lee, C. (2004). Brown at 50: King's dream or Plessy's nightmare?. Cambridge, MA: Civil Rights Project.

Papa, F., Lankford, H., \& Wyckoff, J. (2003). Hiring teachers in NewYork's public schools: Can the principal make a difference?. NY: RAND Corporation. Retrieved June 6, 2008, from: http:// www.emsc.nysed.gov/csl/resources/Hiring_Practices.pdf.

Porter, K. \& Soper, S. (2003). Closing the achievement gap: Urban schools comprehensive school reform connection. Washington, DC: National Clearinghouse for Comprehensive School Reform.

Reinhartz, Judy, and DonBeach. 2004. Educational Leadership: Changing Schools, Changing Rules. New York: NY: Pearson Education Inc.

Ross, S. M., McDonald, A., Alberg, M., \& McSparrin-Gallagher, B. (2005). Urban school reform: Achievement and school climate outcomes for the Knowledge is Power Program. Paper presented at the annual meeting of the American Educational Research Association, Montreal, Canada.

Ross, S. M., McDonald, A., Alberg, M., \& McSparrin-Gallagher, B. (2007). Achievement and climate outcomes for the Knowledge is Power Program in an inner-city middle school. Journal of Education for Students Placed at Risk, 12(2), 137-165.

Sanders, Eugene. (1999). Urban School Leadership: Issues and Strategies. Larchmont, NY: Eye on Education.

Stotko, E. M., Ingram, R., \& Beaty-O'Ferral, M. (2007). Promising strategies for attracting and retaining successful urban teachers. Urban Education, 42(1), 30-51.

Swanson, C. B. (2008). Cities in crisis: A special analytic report on high school graduation. Bethesda, MD: Educational Research Center.

U.S. Bureau of the Census (2004). Income, Poverty, and Health Insurance Coverage in the United States: Report P60. Washington, DC: Author. Retrieved July 11, 2008, from: http:// www.npc.umich.edu/poverty.

U.S. Census Bureau. (1996). Population Projections of the United States by Age, Sex, Race, and Hispanic Origin: 1995 to 2050, Current Population Reports, p.25-1130. Washington, D.C. United States Census Bureau.

U.S. Census Bureau. U.S. Department of Education. (2003-04). Schools and Staffing Survey, 2003-04, Public School Teacher, 
BIA School Teacher, and Private School Teacher Data Files. Washington, D.C.: National Center for Education Statistics.

U.S. Department of Education, National Center for Education Statistics. (2003-04a). Common Core of Data (CCD), public elementary/secondary school universe survey. Washington, DC: Author.

U.S. Department of Education, National Center for Education Statistics. (2003-04b). Schools and staffing survey: teacher questionnaire. Washington, DC: Author.

U.S. Department of Education, National Center for Education Statistics. (2006). Schools and staffing survey (SASS), public school principal questionnaire and private school principal questionnaire 1993-94, 1999-2000, and 2003-04. Washington, DC: Author.

U.S. Department of Commerce, Census Bureau (2003-04). Small area income \& poverty estimates: Local education agency universe survey and school district finance survey (form F-33). Washington, DC: U.S. Department of Education, National Center for Education Statistics, Common Core of Data (CCD).

Villegas, A. M., \& Clewell, B. C. (1998). Increasing teacher diversity by tapping the paraprofessional pool. Theory into Practice, 37(2), 121-130.

Young, E. E., Grant, P. A, Montbriand, C., \&Therriault, D. J. (2001). Educating preservice teachers: The state of affairs. Naperville, IL: North Central Regional Educational Laboratory. Retrieved June 19, 2008, from: http://www.learningpt.org/pdfs/literacy/ preservice.pdf.

Zeichner, Kenneth. (1996a). Educating Teachers for Cultural Diversity. In K Zeichner, S. Melnick, \& M. L. Gomez (Eds.), Currents of Reform in Preservice Teacher Education. New York, NY: Teachers College Press.

(1996b). Educating Teachers for Cultural Diversity in the United States. In M. Craft (Ed.), Teacher Education in Pluralistic Societies: An International Review. London,UK: Falmer Press. 
